\title{
Dorota Leszczyna
}

Uniwersytet Wrocławski, Wrocław

ORCID : 0000-0001-5172-0911

e-mail: d.leszczyna@wp.pl

\section{Gdy rozum śpi, budzą się demony Rzecz o hiszpańskim Oświeceniu*}

\section{Wprowadzenie}

Prezentowany artykuł ma charakter historyczno-filozoficzny. Jego celem jest przedstawienie najważniejszych aspektów związanych z Oświeceniem w Hiszpanii. Staram się w nim pokazać, że mimo trudnych warunków dla rozwoju nowych filozoficznych i naukowych koncepcji, spowodowanych z jednej strony sytuacją społeczno-polityczną - absolutnymi rządami dynastii Burbonów - z drugiej zaś religijną - silną pozycją i wpływem na kształcenie Kościoła katolickiego oraz inkwizycji, oświeceniowe idee zaistniały $\mathrm{w}$ tym kraju, stając się jednym $\mathrm{z}$ kluczowych elementów w jego dążeniu do wyzwolenia rozumu z oków katolickiego dogmatu, tak aby rozum ten stał się gwarantem moralnego i społecznego ładu oraz bazą dla przyszłego liberalnego państwa. Na samym wstępie musimy jednak zaznaczyć, że cele te nie zostały zrealizowane w samym wieku Oświecenia, który - jak zauważają badacze tej problematyki - nie bez przyczyny został określony mianem Oświecenia katolickiego, lecz prawie sto lat później, kiedy z hasłem rozumu, tolerancji i pluralizmu idei ukonstytuowała się Pierwsza Republika Hiszpańska. Była ona w ogromnej mierze dziełem tamtejszych intelektualistów, co

Niniejszy artykuł stanowi rezultat prac badawczych przeprowadzonych w ramach realizacji projektu finansowanego przez Narodowe Centrum Nauki, nr projektu: 2017/27/B/HS1/00562. 
potwierdza fakt, że trzema jej premierami zostali filozofowie związani z nurtami kantyzmu, krazuzyzmu i heglizmu. Nie ma zatem wątpliwości co do tego, że choć Oświecenie z opóźnieniem dotarło do Hiszpanii, to jego pierwszymi, nieśmiałymi emisariuszami, przecierającymi szlaki dla późniejszych konkretnych reform i działań zarówno na polu intelektualnym, jak i społeczno-politycznym, byli tamtejsi siedemnastoi osiemnastowieczni filozofowie, naukowcy, reformatorzy i duchowni.

Punktem wyjścia moich rozważań, a zarazem ich mottem pragnę uczynić tytuł ryciny osiemnastowiecznego hiszpańskiego malarza Francisca de Goi: Gdy rozum śpi, budza się demony (El sueño de la razón produce monstruos). Wchodzi on w skład jego cyklu "Kaprysy” (Los Caprichos), który stanowił satyrę na ówczesne hiszpańskie społeczeństwo, tkwiące w katolickim dogmacie i zabobonie ${ }^{1}$. Za jego sprawą Goya poddał krytyce panujący w Hiszpanii fanatyzm religijny, podsycaną przez Kościół katolicki wiarę w demony i czarownice, opartą na przesłuchaniach, torturach i procesach działalność inkwizycji, brak zainteresowania monarchii losem obywateli, niedostatek reform, które mogłyby poprawić ich los, a także szerzący się wówczas w hiszpańskim społeczeństwie analfabetyzm. W tym miejscu warto przypomnieć, że źródłem tak interpretowanych „Kaprysów” była poezja i filozofia hiszpańskiego Baroku. Na plan pierwszy wysuwa się tutaj postać Francisca de Quevedo (1580-1645) - humanisty, filozofującego pisarza, poety i moralisty, który zasłynął jako twórca konceptyzmu, tj. nurtu poetyckiego mającego na celu zaskakiwanie, zadziwianie, a wręcz szokowanie czytelnika². Pojęcie klucz stanowił w nim „koncept”, tj. nowatorski pomysł, który stawał się podstawą zarówno dla treści, jak i formy tworzonego utworu. Quevedo w 1627 roku wydał pełne alegorii i symboliki dzieło pt. Sueños y discur$s o s^{3}$. Poprzez senne wizje oraz krótkie anegdoty nakreślił w nim krytyczny portret hiszpańskiego społeczeństwa $\mathrm{w}$ dobie panowania ostatnich Habsburgów, czyli Casa de Asturia, celnie wytykając jego największe wady, śmiesznostki i ułomności.

1 Na temat „Kaprysów” Goi i ich możliwych interpretacji pisali między innymi: José Manuel B. López Vázquez, Los caprichos de Goya y su interpretación (Santiago de Compostela: Universidad de Santiago de Compostela, 1982) oraz Gorka López de Munain, „Los Caprichos de Goya. Estampas y textos contra el sueño de la razón”, Revista Sans Soleil 2 (2010-2011): 79-108.

2 Zob. o barokowych prądach poetyckich: Maxime Chevalier, "Conceptisme, culteranisme, agudeza”, Revue XVII siècle 160 (1988): 281-287. Na temat życia i dzieła Quevedo pisał między innymi Pablo Jauralde Pou, Francisco de Quevedo (1580-1645) (Madrid: Castalia, 1999).

${ }^{3}$ Francisco de Quevedo, Sueños y discursos de verdades descubridoras de abusos, vicios y engaños en todos los oficios y estados del mundo (Barcelona: Esteban Liberós, a costa de Juan Sapera, 1627). Zob. też polski przekład tej pracy: Francisco de Quevedo, Sny. Godzina dla każdego, czyli Fortuna mózgiem obdarzona, przeł. Kalina Wojciechowska (Warszawa: PWN, 1982). 
Taka interpretacja „Kaprysów” Goi nie jest jednak jedyną możliwą. Znajdujemy także inną, w której przedstawia się je jako próbę przezwyciężenia oświeceniowej idei rozumu i uwypuklenie znaczenia sfery pozaracjonalnej lub irracjonalnej. Goya przedstawiany jest w niej jako postać wykraczająca poza ramy swojej epoki, jako krytyk rozumu wyznaczający mu granice, poza którymi znajduje się królestwo fantazji. Ta ostatnia, wyzwolona ze sztywnych racjonalistycznych schematów, staje się źródłem tworzenia nowych onirycznych i delirycznych światów. Tym samym Goya i jego „Kaprysy”, z tytułową ryciną na czele, zostali uznani za inspirację między innymi dla reprezentantów surrealizmu, a w filozofii dla tych myślicieli, którzy akcentowali rolę czynników poza- lub ponadracjonalnych. Przykładem takiej wykładni może być praca hiszpańskiego filozofa i eseisty José Ortegi y Gasseta (1883-1955), La leyenda de Goya. Tam o geniuszu Goi pisał Ortega: „Prawda jest taka, że dzieło Goi nie rodzi się z intelektu, można je uznać albo za zwykłe rzemiosło, albo za wizję lunatyka" ${ }^{4}$.

\section{Czy Hiszpanii przydarzyło się Oświecenie? Wybrane opinie hiszpańskich intelektualistów}

Jak wskazałam we wstępie do niniejszego artykułu, charakterystyka hiszpańskiego Oświecenia nie należy do prostych zadań. Wynika to przede wszystkim z faktu, że do dziś nie ma pełnej zgody co do tego, czy idee oświeceniowe dotarły do ojczyzny Cervantesa, a także co do oceny ich wpływu na rozwój tamtejszego społeczeństwa, państwa i kultury $^{5}$. Ta tocząca się od XVIII stulecia dyskusja została zainicjowana przez francuskiego encyklopedystę Nicolasa Masona de Morvilliers'a. W komentarzu do redagowanej przez siebie sekcji Wielkiej encyklopedii francuskiej pt. Dictionnaire de la géographie moderne napisał on: „Wkład Hiszpanii w myśl nowożytną jest praktycznie zerowy. W Hiszpanii brakuje matematyków, fizyków, astronomów, przyrodników. Czego można się jednak spodziewać po narodzie, który aby móc czytać, potrzebuje zgody księdza?"6. W jego ujęciu taki stan rzeczy stanowił rezultat panującego tam absolutystycznego systemu władzy, powiązanego z tradycją państwa wyznaniowego. Uniemożliwiło to zaadaptowanie przez

${ }^{4}$ José Ortega y Gasset, „,Sobre la leyenda de Goya”, w: tenże, Obras completas, t. 9 (Madrid: Fundación José Ortega y Gasset \& Taurus, 2009), 792.

${ }^{5}$ Pisał na ten temat Juan Francisco Fuentes, „Luces y sombras de la Ilustración española", Revista de educación 1 (1988): 9-27. Zob. również Franco Venturi, Utopia and Reform in the Enlightenment (Cambridge: Cambridge University Press, 1975).

${ }^{6}$ Nicolas Masson de Morvilliers, „Espagne”, w: L'Encyclopédie méthodique, t. 1 (Paris: Panckoucke, 1782), 565. 
Hiszpanię nowożytnej idei rozumu, a także opartego na niej projektu otwartego i świadomego swoich praw społeczeństwa obywatelskiego. Tekst Morvilliers'a wywołał poruszenie wśród hiszpańskich intelektualistów - zarówno tych, którzy stanęli w obronie wielkości hiszpańskiej kultury, jak i tych, którzy zgadzali się z tą jakże surową oceną francuskiego autora, pobrzmiewającą za Pirenejami jeszcze przez dwa kolejne stulecia ${ }^{7}$. To natomiast zrodziło trwającą od XVIII wieku debatę na temat kondycji hiszpańskiej kultury, w ramach której poruszono również problem istnienia lub nieistnienia hiszpańskiego Oświecenia. W tej ostatniej sprawie utworzyły się dwa przeciwne obozy. Pierwszy grupował myślicieli, którzy uważali, że w dziejach Hiszpanii zaistniało zjawisko zwane Oświeceniem, choć dokonywali przy tym nierzadko skrajnie odmiennej oceny jego skutków. W skład drugiego zaś wchodzili intelektualiści, którzy wskazywali, że w hiszpańskiej kulturze nie zrodziły się i nie zakorzeniły oświeceniowe idee, widząc w tym bądź to błogosławieństwo, bądź też przyczynę wszystkich jej późniejszych kryzysów i zawirowań.

Pierwszą postacią którą możemy tutaj przywołać, był Marcelino Menéndez Pelayo (1856-1912), hiszpański erudyta, pisarz, filozof, autor kilkutomowego dzieła Historia de los heterodoxos españoles (Historia hiszpańskich heretyków) ${ }^{8}$. Już sam tytuł tej pracy wskazuje, jaki był stosunek Menéndeza Pelayo do oświeceniowych postulatów. Twierdził on, że Oświecenie dotarło do osiemnastowiecznej Hiszpanii, co przesądziło o jej wielkim nieszczęściu. Taka ocena została podyktowana ortodoksyjnym katolicyzmem reprezentowanym przez tego filozofa, który uznał Oświecenie za wiek herezji i zagrożenie dla dogmatów Kościoła katolickiego. Dodatkowo Menéndez Pelayo postawił tezę, iż Hiszpania w przeciwieństwie do Francji, Niemiec czy Wielkiej Brytanii nie wypracowała własnej, narodowej formy realizacji oświeceniowych postulatów, lecz pozostała w tym obszarze mimetyczna, naśladując obcy sposób myślenia. Stąd też uważał on hiszpańskie Oświecenie za epokę negatywna, antykatolicka, za wiek cudzoziemszczyzny oraz zarzewie późniejszych kryzysów Hiszpanii ${ }^{9}$.

7 Na zarzuty Massona de Morvilliers'a odpowiedzieli jako pierwsi Antonio José Cavanilles i Carlos Denina. Pierwszy w 1784 roku opublikował w Paryżu tekst pt. Observaciones del abate Cavanilles sobre el artículo "España" de la Nueva Enciclopedia. Drugi z kolei w 1786 roku w Paryżu napisał i opublikował prace pt. Respuesta a la pregunta: ¿qué se debe a España?. Oba teksty zostały opublikowane w: Ernesto García Camarero, La polémica de la ciencia española (Madrid: Alianza, 1970), 54-71.

8 Marcelino Menéndez Pelayo, Historia de los heterodoxos españoles, 3 vols. (Madrid: Libería de San José, 1880-1882).

9 Pisał o tym Juan Francisco Fuentes, „Luces y sombras de la Ilustración Española”: 11. Zob. też Joaquín Álvarez Barrientos, „El siglo XVIII, según Menéndez Pelayo", Boletín de la Biblioteca de Menéndez Pelayo LXXXII (2006): 297-329. 
Podobną do tej Menéndeza Pelayo opinię prezentował także dwudziestowieczny hiszpański publicysta, pisarz i filozof Ramiro de Maeztu (1875-1936). Był on jednym z reprezentantów filozoficzno-literackiego Pokolenia 1898, który przeszedł dalece posuniętą ewolucję światopoglądową. Jej kulminacja to opublikowane w 1934 roku dzieło La defensa de la Hispanidad, gdzie obecne są idee nacjonalistyczne i antyliberalne. Sam jego autor zginął z rąk zbrojnego ramienia Frontu Ludowego, rozstrzelany bez procesu na początku wojny domowej w Hiszpanii w 1936 roku. Maeztu widział w epoce Oświecenia sprzeniewierzenie się religii katolickiej, która stanowiła dla niego bazę hiszpańskiej kultury we wszystkich jej wymiarach. Kryzysu Hiszpanii upatrywał z kolei w zamiarze sekularyzacji państwa, z jakim po raz pierwszy mieliśmy do czynienia za rządów Ferdynanda VI i Karola III Burbonów ${ }^{10}$.

Co do zaistnienia w Hiszpanii Oświecenia wątpliwości nie mieli również dwaj inni myśliciele: Azorín (1873-1967), poeta i podobnie jak Maeztu przedstawiciel Pokolenia 1898, oraz Eugenio D'Ors (1881-1954), filozof i reprezentant Pokolenia 1914. Od wcześniej omówionych autorów różniła ich jednak ocena znaczenia oświeceniowych idei dla rozwoju Hiszpanii. Azorín uważał wiek XVIII za czas przebudzenia się hiszpańskiego narodu ${ }^{11}$. D'Ors z kolei postawił tezę, że prawdziwa Hiszpania powstała właśnie w XVIII stuleciu ${ }^{12}$.

Odmienne zdanie w kwestii istnienia hiszpańskiego Oświecenia miało liczne grono tamtejszych myślicieli, w tym między innymi Juan Miguel Sánchez de la Campa (1820-1855) - matematyk, filozof i piewca racjonalizmu, który twierdził, że w Hiszpanii nie tylko nie było Oświecenia, ale także i narodowej filozofii, będącej z jednej strony dziełem wolnej myśli, z drugiej zaś owocem wysiłku wspólnotowego, nigdy indywidualnego ${ }^{13}$. Postać Sáncheza de la Campy jest też o tyle interesująca, że uważa się go za jednego z pierwszych w Hiszpanii reprezentantów mesjanizmu. Co więcej, źródeł jego filozofii poszukuje się w mesjanizmie polskiego myśliciela Jana Marii Hoene-Wrońskiego ${ }^{14}$. Praca Sáncheza de la Campy pt. Cuadro sinóptico de la Historia, formado con arreglo al génesis de la Filosofía absoluta z 1854 roku była bowiem wierną kopią idei zawartych w dziele Philosophie absolue de l'Histoire, ou Genèse de l'Humanité autorstwa Hoene-Wrońskiego, które ten opublikował w Paryżu w 1852 roku.

10 Ramiro de Maeztu, „Defensa de la Hispanidad”, Acción Española, 5 (1932): 449-457.

${ }^{11}$ Juan Francisco Fuentes, „Luces y sombras de la Ilustración Española”: 11.

12 Tamże.

${ }^{13}$ Juan Miguel Sánchez de la Campa, „Reflexiones sobre la dirección que conviene dar a los estudios filosóficos", Revista de Instrucción Pública. Literatura y Ciencias 26 (1857): 410-412.

14 Zob. „Juan Miguel Sánchez de la Campa 1820-1885”, dostęp 23.05.2020, www. filosofia.org/ave/003/c024.htm 
Krytycznie o kondycji hiszpańskiej kultury, która od końca XVII wieku zaczęła popadać w coraz głębszą dekadencję, wypowiadali się także poeta i polityk Gaspar Núñez de Arce (1832-1903) oraz związany z nurtem krauzyzmu filozof Gumersindo de Azcárate (1840-1917). Przyczyn fatalnego stanu hiszpańskiej kultury oraz braku w niej oświeceniowej idei rozumu upatrywali oni w fanatycznym katolicyzmie oraz braku wolności myśli i słowa, które są niezbędne do rozwoju filozofii i nauki ${ }^{15}$.

Głos w kwestii hiszpańskiego Oświecenia zabrał również cytowany już wcześniej najwybitniejszy współczesny hiszpański filozof Ortega y Gasset. W jego ocenie idee oświeceniowe nigdy do Hiszpani nie dotar$ł^{16}$. Samo Oświecenie utożsamił on natomiast $\mathrm{z}$ niemieckim pojęciem Bildung, tj. $\mathrm{z}$ wielkim projektem pedagogicznym, z zadaniem kształcenia i wychowywania mas. Brak takiego projektu doprowadził z kolei do głębokiego narodowego kryzysu niemal we wszystkich dziedzinach życia Hiszpanów. „Hiszpania - pisał w jednym ze swoich esejów - to starożytna rasa berberyjska, w której pojawiło się kilka pięknych kobiet i malarzy o genialnym oku, ale $\mathrm{w}$ jej duszy nie zaistnieli nigdy ani Platon, ani Newton, ani Kant. I od stuleci popełnia ona ten sam ciężki grzech przeciwko Duchowi Świętemu - wstręt do idei i teorii" ${ }^{17}$.

\section{Hiszpańska definicja oświecenia według Słownika języka kastylijskiego z 1726 roku}

Oświecenie, nie tylko w Hiszpanii, było pełne problemów i paradoksów. Za przykład może posłużyć brak jego jednej, obowiązującej definicji ${ }^{18}$. W poszczególnych krajach na scharakteryzowanie tego prądu umysłowego używano rozmaitych określeń. We Francji pisano o les lumieres w liczbie mnogiej, podkreślając w ten sposób, że była to jedna z wielu wykładni racjonalizmu, ukierunkowanego krytycznie wobec trady-

15 Zob. prace Gaspara Núñeza de Arce, Causas de la precipitada decadencia y total ruina de la literatura nacional bajo los últimos reinados de la casa de Austria (Madrid: La Real Academia de la Lengue, 1876) oraz Gumersinda Azcárate, El selfgovernment y la monarquía doctrinaria (Madrid: A. de San Martin, 1877). Na ten temat pisałam w artykule „Zarys XIX-wiecznej filozofii hiszpańskiej. Nurty, problemy, inspiracje”, Przeglad Filozoficzny - Nowa Seria 28, 3 (2019): 195-214.

16 José Ortega y Gasset, „Cuaderno de bitácora”, w: tenże, Obras completas, t. 2 (Madrid: Fundación José Ortega y Gasset \& Taurus, 2004), 700.

17 Tenże, „La conservación de la cultura”, w: tenże, Obras completas, t. 1 (Madrid: Fundación José Ortega y Gasset \& Taurus, 2004), 152.

18 Zob. na ten temat Honorata Jakuszko, "Oświeceniowa filozofia”, w: Powszechna encyklopedia filozofii, t. 7 (Lublin: Polskie Towarzystwo Tomasza z Akwinu, 2006), 906. 
cyjnej religii i nietolerancji ${ }^{19}$. W Niemczech mówiono o Aufklärung. We Włoszech z kolei o Illuminismo. W Hiszpanii zanim pojawiło się pojęcie "Oświecenie", tj. ilustración, które zaczęło funkcjonować po 1760 roku, stosowano inne, a mianowicie pojęcie światła rozumu (luz de la razón). Taką właśnie definicję znajdujemy w jednym z najważniejszych osiągnięć hiszpańskiej epoki Oświecenia, jakim był Słownik języka kastylijskiego, publikowany przez Królewską Akademię Hiszpańską w latach 1726-1736. Tam w pierwszym tomie, którego pełny tytuł brzmi: Stownik języka kastylijskiego, w którym tłumaczy się prawdziwe znaczenie słów, ich natury $i$ jakości, można znaleźć następującą definicję „ś́wiatła rozumu” ${ }^{20}$. Jest to "poznanie rzeczy, mające swoje źródło w rozumie, który odróżnia człowieka od zwierzęcia”21. Pojęcie to powiązano też ze „światłem krytyki” (luz de la crítica) lub „światłami krytyki” (luces críticas), gdzie „światło" odnosiło się nie tylko do "pozyskiwania wiedzy, dostępnej jedynie dla nielicznych”, lecz także do "krytycznego użytkowania rozumu względem przesądów, odziedziczonych z przeszłości" 22 .

W tym miejscu warto zaznaczyć, że pierwsze próby zdefiniowania Oświecenia pojawiły się dość późno nie tylko w samej Hiszpanii, lecz także w innych europejskich krajach i publikowanych przez nie słownikach lub encyklopediach. Na przykład w Wielkiej encyklopedii francuskiej nie znajdujemy hasła les lumires, lecz hasło éclairé, oznaczające „kogoś oświeconego" 23 . Z kolei w Wielkiej Brytanii hasło „Oświecenie” pojawiło się po raz pierwszy dopiero w 1775 roku w Stowniku Samuela Johnsona ${ }^{24}$. W Niemczech pojęcie Aufklärung weszło do użycia w latach osiemdziesiątych XVIII stulecia. Duży wpływ miała na to dyskusja Mosesa Mendelssohna i Immanuela Kanta na łamach „Berlinische Monatschrift”. Ten pierwszy opublikował tam tekst pt. W kwestii, co znaczy oświecać, gdzie przeanalizował trzy pojęcia: Kultur, Bildung i Aufklärung, a także występujące między nimi relacje ${ }^{25}$. Drugi natomiast zamieścił w tym czasopi-

19 Pisała na ten temat Dorinda Outram, Panorama Oświecenia, przeł. Joanna Kolczyńska (Warszawa: Arkady, 2006), 24.

${ }^{20}$ Real Academia Española, Diccionario de la lengua castellana, en que se explica el verdadero sentido de las voces, su naturaleza y calidad, con las phrases o modos de hablar, los proverbios o refranes, y otras cosas convenientes al uso de la lengua [...], Compuesto por la Real Academia Española. Tomo primero. Que contiene las letras A.B (Madrid: Imprenta de Francisco del Hierro, 1726).

${ }^{21}$ Pisał o tym Pedro Ruiz Torres, „Reformismo e Ilustración”, w: Vol. 5 de la Historia de España, dirigida por Josep Fontana y Ramón Villares (Barcelona: Critica, 2008), 426-427.

${ }^{22}$ Tamże.

${ }^{23}$ Zob. Dorinda Outram, Panorama Oświecenia, 24.

${ }^{24}$ Tamże.

${ }_{25}$ Moses Mendelssohn, „W kwestii, co znaczy oświecać”, przeł. Radosław Kuliniak, Tomasz Małyszek, w: Wybór pism Mosesa Mendelssohna, red. Radosław Kuliniak, Tomasz Małyszek (Wrocław: Arboretum, 2013), 157-160. 
śmie swoją słynną pracę Czym jest Oświecenie, utożsamiając pojawiający się $\mathrm{w}$ tytule termin $\mathrm{z}$ wyjściem człowieka $\mathrm{z}$ zawinionej przez niego niepełnoletności ${ }^{26}$.

\section{Ramy chronologiczne hiszpańskiego Oświecenia. Dwie wykładnie}

Innym problemem, z jakim musimy się zmierzyć, podejmując próbę przedstawienia najważniejszych znamion hiszpańskiego Oświecenia, są jego chronologiczne ramy. I tak możemy spotkać się z dwiema najbardziej rozpowszechnionymi wykładniami. Różnią się one datą początku tej epoki, podczas gdy jej data końcowa pozostaje w obu przypadkach taka sama i jest to 1808 rok, czyli rok najazdu wojsk Napoleona na Hiszpanię.

\subsection{Pierwsza wykładnia początku Oświecenia w Hiszpanii (lata 1680-1808)}

W pierwszej interpretacji za początek hiszpańskiego Oświecenia uznaje się datę publikacji dzieła El Hombre Práctico o Discursos sobre su Conocimiento y Enseñanza (1680) autorstwa Francisco Gutiérreza de los Ríosa, hrabiego Fernán Núñez. Dzieło to zainicjowało ruch umysłowy zwany "nowatorami" lub „reformatorami” (novatores) ${ }^{27}$. Nowatorzy to działająca w drugiej połowie XVII i w pierwszych dekadach XVIII wieku elitarna i pozostająca $\mathrm{w}$ zdecydowanej mniejszości grupa hiszpańskich intelektualistów, którzy pragnęli zainicjować (innnovar) w Hiszpanii nową naukę i filozofię. Nazwa ta miała początkowo charakter pejoratywny i została ukuta przez przeciwników tej grupy, którzy trawieni lękiem przed wszystkim, co nowe, widząc $\mathrm{w}$ tym zagrożenie dla wiary katolickiej oraz ówczesnego porządku społeczno-politycznego, odrzucali ich reformatorskie projekty ${ }^{28}$. Krytyka nowatorów pochodziła od środowisk pragnących utrzymać status quo, obawiających się, że zmiana systemu rządów mogłaby spowodować rewolucję, a modyfikacja sposobu i treści nauczania mogłaby stać się zagrożeniem dla wiary i pozycji Kościoła.

${ }^{26}$ Immanuel Kant, „Odpowiedź na pytanie »Czym jest Oświecenie «”, przeł. Tomasz Kupś, w: tenże, Dzieła zebrane, t. 6 (Toruń: Wydawnictwo Uniwersytetu Mikołaja Kopernika, 2012), 45-54.

27 Zob. na ten temat między innymi pracę: José Luis Pinillos, „Los novatores en la historia intelectual de España", Boletín de la Real Academia Española 78, 275 (1998): 339-347.

28 Manuel Tuñon de Lara, Julio Valdeón Baruque, Antonio Domínguez Ortiz, Historia Hiszpanii, przeł. Szymon Jędrusiak (Kraków: Universitas, 1997), 352-353. 
Nieufność ta była potęgowana faktem, że nowe idee i teorie pochodziły z krajów „skażonych herezją", tj. z Niemiec, Anglii, Holandii, podczas gdy Hiszpania stanowiła najważniejszy ośrodek walki o czystość wiary katolickiej ${ }^{29}$. Niemniej jednak, jak podkreślają historycy, same teksty nowatorów nie stały się obiektem szykan i zakazów, a inkwizycja nieszczególnie się nimi interesowała ${ }^{30}$. Wynikało to z ich ortodoksyjnego podejścia do kwestii wiary. Nigdy nie występowali oni przeciwko kościelnym dogmatom, unikając chociażby kontrowersyjnego wówczas tematu systemu kopernikańskiego ${ }^{31}$. W filozofii nowatorzy dzielili się na zwolenników René Descartes'a lub Pierre'a Gassendiego. Nowatorzy znajdowali się poza kręgami rządowymi, w związku z czym ich wpływ na ówczesne życie społeczno-polityczne w Hiszpanii był właściwie znikomy. Duże znaczenie mieli natomiast $w$ takich dziedzinach jak chemia i medycyna ${ }^{32}$. Okres działalności „nowatorów” bywa też określany mianem Preoświecenia (preilustación) ${ }^{33}$.

Wśród najważniejszych reprezentantów ruchu nowatorów należy wymienić Nicolása Antonia ${ }^{34}$ (1617-1684), autora Bibliotheca hispana nova (1672) oraz Bibliotheca hispana vetus (wydanego pośmiertnie w 1696 roku). Były to opatrzone krytycznym komentarzem spisy bibliograficzne dzieł wszystkich najważniejszych autorów hiszpańskich aż do jego czasów. Warto wspomnieć także o historyku, archiwiście i bibliofilu Gasparze Ibáñezie de Segovii (1628-1708) ${ }^{35}$. Zasłynął on krytycznym stosunkiem do dość wówczas powszechnych w Hiszpanii mistyfikacji historycznych, które pojawiały się w historycznych dziełach, szczególnie zaś tych dotyczących historii religii i Kościoła katolickiego.

29 Tamże.

30 Tamże.

31 Zob. tamże.

32 Jak pisali autorzy wspomnianej wyżej Historii Hiszpanii: „Lekarze novadores starali się wprowadzić najnowsze osiągnięcia z dziedziny anatomii i fizjologii, tworząc zręby nowoczesnej medycyny". Tamże, 353.

33 Na temat Preoświecenia zob. Antonio Domínguez Ortiz, España, tres milenios de historia (Madrid: Marcial Pons Historia, 2004), 211.

34 Luis Agustín Cordero Medina, Nicolás Antonio. Bibliógrafo americanista (Lima: Ministerio de Educación, 1984) oraz José Solís de los Santos, „Nicolás Antonio (1617-1684)" (con bibliografía), w: Diccionario biográfico y bibliográfico del humanismo español (siglos XV-XVII) (Madrid: Ediciones Clásicas, 2012), 78-81.

35 Aurelio García López, „El novator Gaspar Ibáñez de Segovia y su historia de la Casa de Mondéjar", Revista de Estudios de Guadalajara 31-32 (2004-2005): 45-102. 


\subsection{Druga wykładnia ram czasowych hiszpańskiego Oświecenia (lata 1713-1808)}

W drugiej wykładni za początek Oświecenia w Hiszpanii uznaje się 1713 rok, tj. datę zakończenia wojny o sukcesję hiszpańskiego tronu, toczącej się od 1701 roku między Wielką Brytania, Holandią Austrią z jednej strony a Francja, Hiszpania, Bawarią i Kolonią z drugiej strony ${ }^{36}$. Początkiem konfliktu była śmierć Karola II Habsburga, który nie pozostawił po sobie potomka. Zdążył jednak wyznaczyć na swego następcę Filipa V z dynastii Burbonów. Objął on tron hiszpański w 1700 roku, inicjując okres tak zwanego burbońskiego absolutyzmu oświeconego.

Jak pokazują najnowsze badania historyczne, wizja łącząca początek hiszpańskiego Oświecenia z objęciem tronu przez dynastię Burbonów jest dalece problematyczna, a jej powszechność wynika w dużej mierze z działalności propagandowej, która miała miejsce już za czasów Karola III Burbona (1759-1788) ${ }^{37}$. Nie można jednak zaprzeczyć, że osiemnastowieczna Hiszpania zawdzięczała dynastii Burbonów kilka ważnych kwestii. Po pierwsze wzmocnili oni instytucjonalną stabilność państwa; po drugie zaś podnieśli autorytet władzy królewskiej, nadszarpnięty za panowania ostatnich Habsburgów ${ }^{38}$. Jak podkreślają historycy, bez tych dwóch elementów „nie byłoby możliwe przeprowadzenie przynajmniej części reform postulowanych przez ludzi Oświecenia" ${ }^{\prime 39}$.

\section{Ełapy rozwoju Oświecenia w Hiszpanii}

Oświecenie hiszpańskie nie było nurtem jednorodnym i statycznym, lecz przechodziło transformacje związane ze zmianami o charakterze społecznym i politycznym. W ten sposób możemy wyróżnić trzy główne etapy jego rozwoju, pomijając omówione wcześniej tak zwane Preoświecenie.

${ }^{36}$ Zob. na ten temat: Juan Francisco Fuentes, „Luces y sombras de la Ilustración Española": 13.

${ }^{37}$ "Nie należy wiązać - czytamy w Historii Hiszpanii - tego procesu [procesu rozwoju do idei oświeceniowych] z dojściem do władzy francuskiej dynastii - nowe prądy prędzej czy później musiały ogarnąć także Hiszpanię, leżącą przecież, choć nieco na uboczu, w kręgu kultury europejskiej". De Lara, Baruque, Ortiz, Historia Hiszpanii, 352.

${ }_{38}$ Zob. tamże.

39 Tamże. 


\subsection{Pierwsze Oświecenie (lata 1713-1750)}

Pierwsze Oświecenie przypada na okres rządów króla Filipa V Burbona. Czas ten charakteryzował się położeniem nacisku na tworzenie nowych instytucji kultury. Przykładem mogą być ufundowane pod patronatem monarchii Królewska Akademia Medycyny i Innych Nauk (Regia Sociedad de Medicina y otras Ciencias), Królewska Biblioteka Narodowa (Real Biblioteca) oraz wspomniana wcześniej Królewska Akademia Hiszpańska (Real Academia Española). Król Filip V był zwolennikiem upaństwowienia nauki. Z tego powodu założył Uniwersytet Cervera, który powstał z fuzji sześciu innych katalońskich uczelni. Było to miejsce otwarte na nowe naukowe i filozoficzne idee, oczywiście o tyle, o ile nie zagrażały one pozycji hiszpańskiej korony ${ }^{40}$.

Główne obszary badań, jakie realizowano w ramach pierwszego Oświecenia, stanowiły historia, myśl społeczno-polityczna i ekonomiczna oraz nauki ścisłe.

W pierwszej dziedzinie na uwagę zasługują dwie postaci: Benito Feijoo (1676-1764) - benedyktyn, eseista, poligraf, autor Teatro crítico universal z 1726 roku, a także Gregorio Mayáns (1699-1781) - erudyta, latynista, historyk, prawnik, autor pierwszej biografii Miguela de Cervantesa.

Pierwszy z nich, Feijóo, był promotorem postawy krytycznej i empiryzmu. Nie wykraczał jednak poza granice dogmatu ${ }^{41}$. Badacze jego działalności podkreślają szeroką wiedzę i zdrowy rozsądek tego autora, który ośmieszał i krytykował mity oraz fałszywe mniemania wyrosłe na gruncie historii, filozofii, nauki czy religii ${ }^{42}$. Jego prześmiewcze teksty przysporzyły mu jednak licznych wrogów, którzy nie szczędzili mu ostrej krytyki. Wystarczy wspomnieć o polemikach, jakie toczył z Diego de Torresem i Martínem Martínezem. Spory te dotyczyły astrologii i medycyny ${ }^{43}$. Zostały one przerwane w 1750 roku, kiedy sprzyjający mu król Ferdynand VI Burbon wydał edykt zakazujący publicznego atakowania myśli Feijóo ${ }^{44}$. Zdaniem badaczy Feijóo wskutek nazbyt szerokich zain-

40 „Tylko nieliczne uczelnie - czytamy w Historii Hiszpanii - jak utworzony przez Filipa V Uniwersytet w Cervera [...] otwarły swe podwoje dla nowych idei; większość stawiała im zacięty opór i oświeceniowe koncepcje $z$ trudem torowały sobie drogę na zebraniach towarzysko-naukowych i spotkaniach prywatnych, tak zwanych tertulias. Tamże.

41 Tamże, 354.

${ }^{42}$ Zob. tamże.

${ }^{43} \mathrm{Na}$ temat owych polemik powstała w 2011 roku na Uniwersytecie Autonomicznym w Barcelonie dysertacja doktorska Jesúsa Maríi Galecha Amillano, „,Astrología y medicina para todos los públicos: las polémicas entre Benito Feijoo, Diego de Torres y Martín Martínez y la popularización de la ciencia en la España de principios del siglo XVIII" , dostęp 23.05.2020, www.tdx.cat/handle/10803/32075.

${ }^{44}$ De Lara, Baruque, Ortiz, Historia Hiszpanii, 354. 
teresowań żadnego z obszarów nie zgłębił w sposób rzetelny ${ }^{45}$. Stąd też należy go uznać raczej za „oświecacza” niż oświeceniowego, oryginalnego myśliciela. Jego działalność ograniczała się przede wszystkim do rozpowszechniania istniejących już filozoficznych, historycznych i naukowych idei, nie zaś do prób stworzenia na ich bazie własnej koncepcji.

Mayáns z kolei był wrogiem religijnego fanatyzmu ${ }^{46}$. Krytykował wiarę $\mathrm{w}$ elementy nadprzyrodzone i próby wykorzystania ich $\mathrm{w}$ opisie historii Hiszpanii, zwłaszcza zaś w historii hiszpańskiego Kościoła. Wydał z tego powodu pracę, tak zwaną Refutację, napisaną przez wspomnianego już wcześniej „nowatora” Nicolása Antonio, w której ten krytykował tak zwane fałszywe kroniki. Wskutek tej publikacji jego zaciekłym wrogiem stał się wpływowy wówczas kardynał Molina, Prezydent Rady Kastylii i Główny Inkwizytor ${ }^{47}$. Badacze myśli Mayánsa podkreślają jego niezwykłą erudycję oraz humanistyczne ukierunkowanie. Uznają go nawet za "ostatniego z wielkich humanistów odrodzeniowych” lub za „pierwszego pośród najznakomitszych ludzi Oświecenia" ${ }^{\prime 4}$.

W obszarze myśli politycznej, społecznej i ekonomicznej na uwagę zasługuje Jerónimo de Ustáriz (1670-1732) ${ }^{49}$. Jego główne dzieło pt. Theórica y práctica de Comercio y de Marina z 1717 roku zostało przetłumaczone na kilka języków, w tym na angielski (1751) francuski (1753), a także holenderski i włoski. Było ono cytowane między innymi przez Voltaire'a w jego Essai sur les mœurs oraz przez Adama Smitha w The Wealth of Nations (1776).

W naukach ścisłych z kolei wyróżniali się Tomás Vicente Tosca y Mascó (1651-1723) oraz Antonio Ulloa (1716-1795). Pierwszy to matematyk, architekt, filozof, teolog, zaliczany do nurtu nowatorów ${ }^{50}$. Był on autorem dzieła El Compendio Matemático (1721), w którym opowiedział się za stanowiskiem mechanicyzmu, powołując się na Galileusza, Descartes'a oraz Gassendiego. Drugi z kolei jako jeden z pierwszych

45 Tamże. Zob. też Juan Francisco Fuentes, „Luces y sombras de la Ilustración Española": 15.

46 Tamże. Zob. też na temat życia i dzieła Mayánsa: Antonio Mestre Sanchis, Mayans y Siscar y el pensamiento ilustrado español contra el absolutismo (León: Universidad de León, 2007).

${ }^{47}$ De Lara, Baruque, Ortiz, Historia Hiszpanii, 354.

48 Tamże.

49 Zob. na temat Ustáriza M. Bitar Letayf, Economistas españoles del siglo XVIII (Madrid: Ediciones Cultura Hispánica, 1968) oraz Fernández Durán, Reyes, „Gerónimo de Uztariz y Hermiaga", w: Diccionario Biográfico Español, Real Academia de la Historia, dostęp 24.05.2020, http://dbe.rah.es/biografias/15370/geronimo-de-uztariz-yhermiaga.

50 Zob. Vicenç M. Rosselio, „Tomàs V. Tosca y su entorno ilustrado en Valencia. Obra autógrafa y atribuciones", Ería. Revista Cuatrimestral de Geografía 64-65 (2004): 159-176. 
w Hiszpanii znał naukę Isaaca Newtona. Świadczy o tym dzieło, które napisał wspólnie z innym hiszpańskim naukowcem i wojskowym Jorge Juanem pt. Observaciones Astronómicas y Físicas z $1748^{51}$.

\subsection{Pełnia Oświecenia (lata 1750-1787)}

Drugi etap rozwoju hiszpańskiego Oświecenia to okres rządów króla Ferdynanda VI Burbona oraz króla Karola III Burbona. Epoka ta określana jest przez historyków jako czas wielkich reform ${ }^{52}$. Dokonano wówczas między innymi spisu gruntów i nieruchomości, regulacji stosunków z Państwem Kościelnym, wskutek podpisanego w 1753 roku konkordatu, reformy edukacji, reform gospodarczych i społecznych. Władcy zadbali także o fundację nowych szkół, akademii oraz instytucji kultury i nauki. Wszystko to było możliwe dzięki zdolnym reformatorom obecnym na hiszpańskim dworze. Wśród nich na szczególną uwagę zasługuje Don Cenón de Somodevilla, markiz de la Ensenada, zwany najwybitniejszym ministrem Ferdynanda VI. Był on zwolennikiem jezuitów i przeciwnikiem encyklopedystów ${ }^{53}$. Dążył do zachowania dobrych stosunków między monarchą a inkwizycją i Wielkimi Kolegiami. Zasłynął za sprawą projektu robót publicznych. Przeprowadził także kataster, dzięki któremu zwiększyły się dochody skarbu państwa. Mimo krytycznego podejścia do oświeceniowych idei filozoficznych Somodevilla pragnął ożywić kontakty naukowe z zagranica, aby zmniejszyć w ten sposób zacofanie Hiszpanii w stosunku do innych europejskich narodów.

Innym reformatorem obecnym na królewskim dworze był Pedro Rodríguez de Campomanes, cieszący się poparciem króla Karola III Burbona, klasycysta i prawnik, autor wielu reform, w tym reformy wyborów do władz municypalnych i liberalizacji handlu zbożem ${ }^{54}$. Zasłynął wydaleniem z Hiszpanii jezuitów i zwalczaniem nadużyć kościelnej jurysdykcji. Uważał się za rojalistę i wspierał Karola III w jego walce o zapewnienie sobie kontroli nad Kościołem. Campomanes był także pomysłodawcą utworzenia w Hiszpanii międzyklasowych towarzystw ekonomicznych, choć w rezultacie udało mu się zmobilizować jedynie

51 Zob. „Daniel Torregrosa, Antonio de Ulloa, el marino que leía a Newton”, dostęp 24.05.2020,_https://culturacientifica.com/2018/04/20/antonio-de-ulloa-el-marino-que-leia-a-newton/.

${ }^{52}$ Tuñon de Lara, Valdeón Baruque, Domínguez Ortiz, Historia Hiszpanii, 354.

53 Tamże, 355.

${ }^{54}$ Jak czytamy w Historii Hiszpanii o Campomasie: „był to człowiek o wielkiej kulturze klasycznej i prawniczej [...]. Nieugięty charakter i niepohamowana niechęć do niektórych osób sprawiały, że z jego poczynań przebijał na przemian despotyzm i duch oświeceniowy". Tamże. 
najwyższe warstwy społeczne ${ }^{55}$. Towarzystwa te powstały w Madrycie, Saragossie czy Sewilli. Najważniejszym spośród nich było jednak Baskijskie Towarzystwo Przyjaciół Kraju. Tworząca je grupa arystokratów dała początek słynnemu w Hiszpanii seminarium w miejscowości Vergara, które gromadziło wybitnych fachowców, a także ufundowało bogatą w zbiory bibliotekę, w której znalazła się między innymi Wielka encyklopedia, sprowadzona z Francji dzięki specjalnemu pozwoleniu władz kościelnych ${ }^{56}$.

\subsection{Kryzys Oświecenia i oświeconego absolutyzmu (lata 1788-1808)}

Kryzys Oświecenia przypadł na okres rządów króla Karola IV Burbona (1788-1808). Doszło wówczas do zahamowania reform wskutek paniki, jaka pojawia się w momencie wybuchu Wielkiej Rewolucji Francuskiej. Ministrowie królewscy, w tym Campomanes, a także José Moñino y Redondo, hrabia Floridablanca, następnie zaś minister Carl August von Ehrensvärd przyjęli postawę antyrewolucyjna, która spowodowała zaniechanie działań na rzecz rozwoju Hiszpanii. Nie oznacza to jednak, że w tamtym czasie nie pojawiły się tam osobowości otwarte na nowe prądy umysłowe, dążące do zmiany istniejącego porządku. Nie było wśród nich jednak wielu intelektualistów głoszących rewolucyjne idee społeczno-polityczne. Jednym z tych nielicznych był José Marchena (1768-1821), polityk, liberał, zwany „sfrancuziałym”57. Jego przydomek wynikał z reprezentowanych przez niego radykalnych poglądów związanych $\mathrm{z}$ hasłami rewolucji francuskiej. Marchena przez wiele lat działał we Francji, gdzie uznawano go za wybitnego humanistę. Opinia ta spowodowała, że przez krótki czas służył na dworze Jana I Bonaparte, który zasiadł na hiszpańskim tronie w 1808 roku.

Inną wybitną postacią tamtego okresu był Gaspar Melchor de Jovellanos (1744-1811), pisarz, polityk, prawnik i według wielu historyków postać najlepiej wyrażająca ducha hiszpańskiego Oświecenia ${ }^{58}$. Uważany za umiarkowanego liberała, a zarazem ortodoksyjnego katolika,

55 Zob. tamże, 355-356. Pisali też na ten temat Paula Demerson, Francisco Aguilar Piñal, Las Sociedades Económicas de Amigos del País en el siglo xvin. Guía del investigador (San Sebastián: Gráficas Izarra, 1974).

56 Tuñon de Lara, Valdeón Baruque, Domínguez Ortiz, Historia Hiszpanii, 355. Zob. również na ten temat Francisco Aguilar Piñal, „Los reales Seminarios de Nobles en la política ilustrada española”, Cuadernos Hispanoamericanos 356 (1980): 329-349.

57 Zob. Tuñon de Lara, Valdeón Baruque, Domínguez Ortiz, Historia Hiszpanii, 357. Na temat życia i działalności tego wybitnego humanisty pisał między innymi Fuentes, Juan Francisco, José Marchena: biografía política e intelectual (Barcelona: Crítica, 1989).

58 O tym myślicielu zob. Javier Varela, Jovellanos (Madrid: Alianza Editorial, 1988). 
pragnął, w przeciwieństwie do rewolucjonisty Marcheny, zachować to, co wartościowe $\mathrm{w}$ hiszpańskiej tradycji. Znany był z zaangażowania w reformy pedagogiczne. Celem swoich dążeń uczynił edukowanie i wychowywanie hiszpańskiego społeczeństwa w duchu oświeceniowych wartości. Założył Instytut Asturyjski, tworząc tam katedry nauk ścisłych i stosowanych, które do tamtej pory działały tylko poza murami uniwersytetów. Mimo ortodoksyjnego podejścia do kwestii wiary Jovellanos popadł w konflikt z inkwizycją. Ta ostatnia zakazała popularyzacji jego dzieła Informe sobre la ley agraria, w którym widziała zagrożenie dla przywilejów Kościoła. Ponadto Jovellanos należał do stowarzyszenia założonego przez skazanego przez inkwizycję za herezję Pabla de Olavide $(1725-1803)^{59}$, człowieka niezwykle oczytanego, zwłaszcza w obszarze filozofii francuskiej. Został on przedstawicielem rządu, nadzorującym projekt zakładania osiedli na terenach pustynnych Sierra Morena (Andaluzja). W tym przedsięwzięciu oprócz Hiszpanów brali też udział Niemcy i Szwajcarzy, co wzbudziło zaniepokojenie inkwizycji. Olavide otwarcie rozmawiał z nimi na tematy filozoficzne i religijne. Wskutek donosu oskarżono go o grzech herezji. Został postawiony przed trybunałem inkwizycji i skazany na osiem lat więzienia oraz konfiskatę majątku. Jak pisał o procesie Olavide i wyroku inkwizycji Marcelino Menéndez Pelayo, „Olavide wyszedł na salę procesową przeraźliwie blady, prowadzony przez dwóch członków Świętego Oficjum. Wysłuchał z wielkim przerażeniem sentencji wyroku i odrzekł: »Ja nigdy nie utraciłem wiary, chociaż tak twierdzi oskarżyciel«, po czym upadł zemdlony na ziemię $^{\prime \prime 60}$. Zarówno proces, jak i wyrok odbiły się szerokim echem w całej Europie, wywołując oburzenie. Ostatecznie dzięki pomocy przyjaciół Olavide zbiegł do Francji.

W tym miejscu warto też wspomnieć o innej ofierze inkwizycji, jaką był Ramón de Salas, prawnik i wykładowca uniwersytecki. Został oskarżony o bezbożnictwo i „,wolteryzm” (volterianismo), rozpowszechniał bowiem wśród swoich studentów idee Voltaire'a, Paula Holbacha i Jeana-Jacques'a Rousseau ${ }^{61}$.

${ }^{59} \mathrm{Na}$ temat procesu Olavide zob. Fuentes, „Luces y sombras de la Ilustración Española": 23.

${ }^{60}$ Marcelino Menéndez Pelayo, Historia de los heterodoxos, t. 2 (Madrid: B.A.C., 1956), 572.

${ }^{61}$ Fuentes, „Luces y sombras de la Ilustración Española”: 18. 


\section{Zakończenie}

Na zakończenie chciałabym dokonać swoistego podsumowania i wskazać najważniejsze cechy Oświecenia w Hiszpanii. Te z kolei można sprowadzić do kilku kwestii.

Po pierwsze, reprezentanci tego ruchu byli, właściwie bez wyjątków, ortodoksyjnymi katolikami. Nie występowali wśród nich ani deiści, ani ateiści. Uważali, że „światło przyrodzonego, ludzkiego rozumu” podporządkowuje się „światłu rozumu boskiego”, że „rozum i religia są dziełami Stwórcy", w związku z czym nie zachodzi między nimi sprzeczność ${ }^{62}$. To spowodowało określenie przez część komentatorów tej hiszpańskiej epoki mianem Oświecenia katolickiego, co z kolei dało argument innym badaczom, którzy kwestionowali tezę, iż w Hiszpanii mieliśmy do czynienia $\mathrm{z}$ ideami oświeceniowymi $\mathrm{w}$ pełnym tego słowa znaczeniu. Dla nich bowiem oświeceniowa idea rozumu oznaczała rozum wolny, krytyczny i samodzielny. W Hiszpanii z kolei racjonalna krytyka musiała mieścić się (i mieściła) w granicach katolickiego dogmatu ${ }^{63}$.

Po drugie, w hiszpańskim Oświeceniu mieliśmy do czynienia z podwójną cenzurą ${ }^{64}$. Nowe idee podlegały tam cenzurze politycznej i religijnej. Za cenzurę polityczną odpowiadało Consejo de Castilla, tj. Rada Kastylii - utworzona jeszcze za rządów królów katolickich. Z kolei za cenzurę religijną odpowiadała inkwizycja. To zaś miało negatywny wpływ na rozwój idei postępowych, wykluczało bowiem jakąkolwiek krytykę monarchii i Kościoła. Eliminowało też skutecznie wolność słowa i druku. Przykładem może być Indeks Ksiąg Zakazanych, gdzie w 1756 roku znalazło się dzieło Montesquieugo $O$ duchu praw, a od 1762 roku wszystkie prace Volteire'a i Rousseau ${ }^{65}$.

Po trzecie wreszcie, hiszpańskie Oświecenie cechował dalece posunięty elitaryzm ${ }^{66}$. Idee oświeceniowe były tam udziałem jedynie elit (arystokracji i części kleru). Reszta społeczeństwa nie miała do nich dostępu i - jak pisał historyk Martinez Schaw - „żyła w zacofaniu gospodarczym, nierówności społecznej, analfabetyzmie i tradycyjnej religii" ${ }^{\prime 67}$.

${ }^{62}$ Ruiz Torres, Reformismo e Ilustración, 432-433.

63 Zob. tamże.

${ }^{64} \mathrm{Na}$ temat cenzury w oświeceniowej Hiszpanii zob. L. Domergue, Censure et Lumières dans l'Espagne de Charles III (París: Éditions du C.N.R.S, 1982).

65 Zob. Fuentes, „Luces y sombras de la Ilustración Española”: 18.

${ }^{66}$ Zob. Antonio Mestre, Pablo, Pérez García, „La cultura en el siglo XVIII español”, w: Luis Gil Fernández y otros, La cultura española en la Edad Moderna. Historia de España XV (Madrid: Istmo, 2004), 387-388.

${ }_{67}$ Carlos Martínez Shaw, El Siglo de las Luces. Las bases intelectuales del reformismo (Madrid: Historia, 1996), 9. 
W tym miejscu warto jeszcze wspomnieć o sposobach popularyzacji idei oświeceniowych $w$ Hiszpanii. Idee te rozprzestrzeniały się wśród elit za sprawą spotkań tak zwanych tertulias, akademii, a w dalszej kolejności tworzonych wówczas rozmaitych towarzystw. Mniejsze znaczenie miały natomiast salony prowadzone przez damy ${ }^{68}$. Nie oznacza to jednak, że takowe miejsca spotkań w ogóle nie istniały. Przykładem może być salon Maríi Francisci de Sales Portocarrero, VI hrabiny de Montijo, hrabiny de Bonavante, a także księżnej de Alba. Należy też przypomnieć o Towarzystwie Dam (Junta de Damas), działającym w ramach założonego przez króla Karola III Burbona Sociedad Económica Matritense de Amigos del País ${ }^{69}$.

Wszystkie powyższe cechy hiszpańskiej epoki Oświecenia wskazuja, że oświeceniowe idee dotarły do Hiszpanii w dość ograniczonym zakresie i poruszyły umysły i serca nielicznej grupy tamtejszych intelektualistów. Nie można jednak nie zauważyć roli, jaką odegrały one w położeniu fundamentów pod nową ideę świeckiej, liberalnej i otwartej Hiszpanii, która z pełną mocą ujawniła się w drugiej połowie XIX stulecia. Możemy $w$ ten sposób zaryzykować stwierdzenie, że to właśnie wówczas, tj. sto lat później, mieliśmy do czynienia z prawdziwym hiszpańskim Oświeceniem i pierwszym poważnym starciem między Hiszpanią rozumu a Hiszpanią dogmatu. To wtedy doszło bowiem do załamania się obowiązującego porządku społeczno-politycznego (Antiguo regimen), charakteryzującego się monarchicznym despotyzmem i dominacją Kościoła katolickiego. Załamanie to nie przebiegło niestety bezkrwawo, był to bowiem czas licznych rewolucji, buntów i wojen domowych. W wydarzeniach tych ważną rolę odegrali tamtejsi intelektualiści, którzy z orężem idei oświeceniowych toczyli walkę na dwóch frontach: o podniesienie poziomu intelektualnego Hiszpanii w oparciu o recepcje nowożytnej europejskiej nauki i filozofii oraz o modernizację struktur prawno-państwowych, co przejawiało się $\mathrm{w}$ ich działaniach na rzecz obalenia monarchii i ukonstytuowania $\mathrm{w}$ jej miejsce republiki. Walkę, której losy przechylały się raz w jedną, raz w drugą stronę, kontynuowano także w pierwszej połowie XX wieku. Dobitnym tego przykładem jest postać Ortegi y Gasseta, który w filozofii pojętej jako stopniowe oświecanie człowieka, wyzwalanie go z niepełnoletności i nauczanie krytycznego myślenia widział najważniejsze narzędzie stworzenia nowej, republikańskiej i europejskiej Hiszpanii, a także, a może przede wszystkim, nowej, zjednoczonej i pełnej witalnej energii Europy.

68 Pisał na ten temat Torres, Reformismo e Ilustración, 427-428.

${ }^{69}$ Zob. tamże. 


\section{Bibliografia}

Aguilar Piñal Francisco. 1980. „Los reales Seminarios de Nobles en la política ilustrada española". Cuadernos Hispanoamericanos 356: 329-349.

Agustín Cordero Medina Luis. 1984. Nicolás Antonio. Bibliógrafo americanista. Lima: Ministerio de Educación.

Solís de los Santos José. 2012. „Nicolás Antonio (1617-1684)”. W: Diccionario biográfico y bibliográfico del humanismo español (siglos XV-XVII). Madrid: Ediciones Clásicas: 78-81.

Álvarez Barrientos Joaquín. 2006. „El siglo XVIII, según Menéndez Pelayo”. Boletín de la Biblioteca de Menéndez Pelayo LXXXII: 297-329.

Azcárate Gumersindo. 1877. El selfgovernment y la monarquía doctrinaria. Madrid: A. de San Martin.

Bitar Letayf M. 1968. Economistas españoles del siglo XVIII. Madrid: Ediciones Cultura Hispánica.

Chevalier Maxime. 1988. „Conceptisme, culteranisme, agudeza”, Revue XVII siècle 160: 281-287.

„Daniel Torregrosa, Antonio de Ulloa, el marino que leía a Newton”. Dostęp 24.05.2020._https://culturacientifica.com/2018/04/20/antonio-de-ulloa-el-marino-que-leia-a-newton/.

Demerson Paula, Francisco Aguilar Piñal. 1974. Las Sociedades Económicas de Amigos del País en el siglo xvin. Guía del investigador. San Sebastián: Gráficas Izarra.

Diccionario de la lengua castellana, en que se explica el verdadero sentido de las voces, su naturaleza y calidad, con las phrases o modos de hablar, los proverbios o refranes, y otras cosas convenientes al uso de la lengua [...]. 1726. Compuesto por la Real Academia Española. T. I. Que contiene las letras A.B. Madrid: Imprenta de Francisco del Hierro.

Domergue Lucienne. 1982. Censure et Lumières d, ans l'Espagne de Charles III. París: Éditions du C.N.R.S.

Domínguez Ortiz Antonio. 2004. España, tres milenios de historia. Madrid: Marcial Pons Historia.

Fernández Durán Reyes. „Gerónimo de Uztariz y Hermiaga”. W: Diccionario Biográfico Español. Real Academia de la Historia. Dostęp 24.05.2020. http://dbe.rah.es/biografias/15370/geronimo-de-uztariz-y-hermiaga

Fuentes Juan Francisco. 1988. „Luces y sombras de la Ilustración española”. Revista de Educación 1: 9-27.

Fuentes Juan Francisco. 1989. José Marchena: biografía política e intelectual. Barcelona: Crítica.

García Camarero Ernesto. 1970. La polémica de la ciencia española. Madrid: Alianza.

García López Aurelio. 2004-2005. „El novator Gaspar Ibáñez de Segovia y su historia de la Casa de Mondéjar". Revista de Estudios de Guadalajara 31-32: 45-102. 
Jakuszko Honorata. 2006. „Oświeceniowa filozofia”. W: Powszechna encyklopedia filozofii. T. 7. Lublin: Polskie Towarzystwo Tomasza z Akwinu: 906-915.

Jauralde Pou Pablo. 1998. Francisco de Quevedo (1580-1645). Madrid: Castalia. „Juan Miguel Sánchez de la Campa 1820-1885”. Dostęp 23.05.2020. www. filosofia.org/ave/003/c024.htm

Kant Immanuel. 2012. „Odpowiedź na pytanie »Czym jest Oświecenie«". Przeł. Tomasz Kupś. W: Immanuel Kant. Dzieła zebrane. T. 6. 45-54. Toruń: Wydawnictwo Uniwersytetu Mikołaja Kopernika.

Leszczyna Dorota. 2019. „Zarys XIX-wiecznej filozofii hiszpańskiej. Nurty, problemy, inspiracje". Przeglad Filozoficzny - Nowa Seria 28: 195-214.

López de Munain Gorka. 2010-2011. „Los Caprichos de Goya. Estampas y textos contra el sueño de la razón". Revista Sans Soleil 2: 79-108.

López Vázquez José Manuel B. 1982. Los caprichos de Goya y su interpretación. Santiago de Compostela: Universidad de Santiago de Compostela.

Maeztu Ramiro de. 1932. „Defensa de la Hispanidad”. Acción Española 5: $449-457$.

Martínez Shaw Carlos. 1996. El Siglo de las Luces. Las bases intelectuales del reformismo. Madrid: Historia.

Mendelssohn Moses. 2013. „W kwestii co znaczy oświecać”. Przeł. Radosław Kuliniak, Tomasz Małyszek. W: Wybór pism Mosesa Mendelssohna, red. Radosław Kuliniak, Tomasz Małyszek. 157-160. Wrocław: Arboretum.

Menéndez Pelayo Marcelino. 1880-1882. Historia de los heterodoxos españoles, 3 vols., Madrid: Libería de San José.

Menéndez Pelayo Marcelino. 1956. Historia de los heterodoxos. T. 2. Madrid: B.A.C.

Mestre Antonio Pablo, Pérez García. 2004. „La cultura en el siglo XVIII español". W: La cultura española en la Edad Moderna. Historia de España XV, Luis Gil Fernández y otros. 387-388. Madrid: Istmo.

Mestre Sanchis Antonio. 2007. Mayans y Siscar y el pensamiento ilustrado español contra el absolutismo. León: Universidad de León.

Núñez de Arce Gaspar. 1876. Causas de la precipitada decadencia y total ruina de la literatura nacional bajo los últimos reinados de la casa de Austria. Madrid: La Real Academia de la Lengue.

Ortega y Gasset José. 2004. „Cuaderno de bitácora”. W: José Ortega y Gasset, Obras completas. T. 2. Madrid: Fundación José Ortega y Gasset \& Taurus.

Ortega y Gasset José. 2004. „La conservación de la cultura”. W: José Ortega y Gasset, Obras completas. T. 1. Madrid: Fundación José Ortega y Gasset \& Taurus.

Ortega y Gasset José. 2009. „Sobre la leyenda de Goya”. W: Ortega y Gasset José, Obras completas. T. 9. Madrid: Fundación José Ortega y Gasset \& Taurus.

Outram Dorinda. 2006. Panorama Oświecenia. Przeł. Joanna Kolczyńska. Warszawa: Arkady.

Pinillos José Luis. 1998. „Los novatores en la historia intelectual de España”, Boletín de la Real Academia Española 78: 339-347. 
Quevedo Francisco de. 1627. Sueños y discursos de verdades descubridoras de abusos, vicios y engaños en todos los oficios y estados del mundo. Barcelona: Esteban Liberós.

Quevedo Francisco de. 1982. Sny. Godzina dla każdego, czyli Fortuna mózgiem obdarzona. Przeł. Kalina Wojciechowska. Warszawa: PWN.

Rosselló Vicenç M. 2004. „Tomàs V. Tosca y su entorno ilustrado en Valencia. Obra autógrafa y atribuciones". Ería. Revista Cuatrimestral de Geografía 64-65: 159-176.

Ruiz Torres Pedro. 2008. „,Reformismo e Ilustración”. W: Vol. 5 de la Historia de España, ed. Josep Fontana, Ramón Villares. 426-427. Barcelona: Critica.

Sánchez de la Campa Juan Miguel. 1857. „Reflexiones sobre la dirección que conviene dar a los estudios filosóficos". Revista de Instrucción Pública, Literatura y Ciencias 26: 410-412.

Tuñon de Lara Manuel, Julio Valdeón Baruque, Antonio Domínguez Ortiz. 1997. Historia Hiszpanii. Przeł. Szymon Jędrusiak, Kraków: Universitas.

Varela Javier. 1988. Jovellanos. Madrid: Alianza Editorial.

Venturi Franco. 1975. Utopia and Reform in the Enlightenment. Cambridge: Cambridge University Press.

\section{Streszczenie}

Celem niniejszego artykułu jest przedstawienie najważniejszych cech Oświecenia w Hiszpanii. Rozpoczynam od dyskusji, jakie toczyły się na temat tej epoki wśród hiszpańskich myślicieli. Następnie podejmuję problem pierwszej definicji Oświecenia, jaka pojawiła się w 1726 roku w Słowniku języka kastylijskiego. Przedstawiam ramy chronologiczne tej epoki w Hiszpanii, a także główne etapy jej rozwoju w postaci Preoświecenia, pierwszego Oświecenia, pełni Oświecenia i kryzysu Oświecenia.

Słowa kluczowe: Oświecenie, Hiszpania, rozum, nowatorzy, Inkwizycja, historia, dynastia Burbonów

\section{The Sleep of Reason Produces Monsters On the Spanish Enlightenment}

\section{Summary}

The purpose of this article is to present the most important features of the Enlightenment in Spain. I start by presenting the discussions that took place on the subject of the Enlightenment among Spanish thinkers. Then, I deal with the problem of the first definition of the Enlightenment, which appeared in 1726 in 
the Dictionary of the Castilian Language. I also present the chronological framework of this age in Spain as well as the main stages of its development in the form of the Pre-Enlightenment, First Enlightenment, Mature Enlightenment and the Crisis of the Enlightenment.

Keywords: Enlightenment, Spain, reason, innovators, Inquisition, history, Bourbon dynasty 